\title{
Ensaio fotográfico - Experiências de rua no bairro da Bela Vista
}

\author{
Lilanando Léo
}

"Pessoa em situação de rua" é o conceito atual mais utilizado para se referir àqueles que possuem em comum os vínculos familiares fragilizados e a inexistência de moradia convencional, utilizando-se de locais públicos (praças, jardins, canteiros, marquises, viadutos) e áreas degradadas (prédios abandonados, ruínas) como espaço de moradia.

Fatores socioeconômicos tais quais êxodo rural, crescimento do subemprego e pauperização afetam esses sujeitos que, excluídos do circuito de trabalho e consumo, têm sua categoria de sujeito de direito subtraída, engrossando o caldo de uma população socialmente ameaçadora, economicamente desnecessária e fisicamente eliminável, cuja existência é limitada à sobrevivência diária e destituída de planejamentos em longo prazo.

O ponto de partida deste trabalho é a observação participante, que privilegia a experiência direta e as práticas cotidianas das pessoas em situação de rua, buscando compreender o universo material e simbólico que enredam as diversas trajetórias de exclusão.

Quando enxergada de perto e de dentro, a pessoa em situação de rua não é vista como o lumpemproletariado inútil, mas sim como sujeito responsável por engendrar uma práxis social caracterizada pela articulação dos laços imprescindíveis à sua sobrevivência, a qual não passaria sem a especialização na improvi- 
sação material e manipulação de relações sociais, elaborando uma verdadeira prática de "viração" (capacidade de "se virar") nas ruas da metrópole.

As fotografias, submetidas ao nono volume da revista Humanidades em diálogo, foram capturadas junto às pessoas em situação de rua organizadas em torno da "maloca" na Praça Pérola Byington, bairro da Bela Vista na capital de São Paulo, entre outubro de 2016 e janeiro de 2017, e constituem trabalho de antropologia visual.

O registro difunde uma cultura marginal, subvisualizada e negligenciada, que não só reflete a desigualdade aparentemente imotivada da sociedade de classes, mas também equivale a uma ressignificação do modo de vida dominante, na medida em que é capaz de subjetivar o espaço apropriado ao planejamento urbano e estimular a reutilização de utensílios descartáveis deixados pela população sedentária, numa vida nômade e de tecnologia rudimentar.

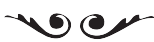

Lilanando Léo é graduando em Giências Sociais pela Universidade de São Paulo. leonardo.santos.silva@usp.br 